\title{
A Feminist Love Letter to Stuart Hall; or What Feminist Cultural Studies Needs to Remember
}

\section{ELSPETH PROBYN}

UNIVERSITY OF SYDNEY

I need to preface these brief remarks with a caveat. I was to write of Hall's contribution to forging feminist cultural studies, the intellectual project I have felt affiliated with across my academic life, and certainly that which has inspired and formed me. But I don't feel entitled to write of 'feminist cultural studies' in the way that others, such as Lucy Bland, Janice Winship, Angela McRobbie and Charlotte Brunsdon can. I wasn't there when the Women Studies Group at the Centre for Contemporary Cultural Studies struggled with 'the dilemma' of 'whether to conquer the whole of cultural studies and only then to make a feminist critique of it, or whether to focus on the "woman question" from the beginning'. ${ }^{1}$ The group did conceptual work across the disciplines of history, anthropology, psychology and literary studies, and grappled with theoretical movements influenced by figures as varied as Lacan, Marx and Foucault and across sites such as popular culture, regimes

ISSN 1837-8692

Cultural Studies Review 2016. ( 2016 Elspeth Probyn. This is an Open Access article distributed under the terms of the Creative Commons Attribution 4.0 Unported (CC BY 4.0) License

(https://creativecommons.org/licenses/by/4.0/), allowing third parties to copy and redistribute the material in any medium or format and to remix, transform, and build upon the material for any purpose, even commercially, provided the original work is properly cited and states its license. 
of gendered work and eighteenth-century novels. At the same time, and in their words, 'the Group also felt it wanted to do concrete work rather than engaging theoretical wrangles'.2 Across the chapters in Women Take Issue I see dedicated feminists poring over texts, their own and others, and then heading to the streets, the factories and girls' bedrooms to understand how, where and with what effect gendered relations were being reproduced. It is a picture of scholarly intent a bit at odds with Hall's description in hindsight of how feminism roared into the project of cultural studies:

For cultural studies (in addition to many other theoretical projects), the intervention of feminism was specific and decisive. It was ruptural ... As a thief in the night, it broke in, interrupted, made an unseemly noise, seized the time, crapped on the table of cultural studies. ${ }^{3}$

In her passionate and intellectually generous accounting of the relationship of feminists and feminism to sociology, Bev Skeggs astutely notes that the ruptural intervention of feminism described by Hall ... is a positive re-ordering of knowledge: feminists re-inscribe the object and subject of culture, re-imagine the workings of power and expose the mechanisms by which knowledge can be achieved'. ${ }^{4}$ Skeggs's 'dirty history of feminism and sociology' is a crucial intervention, cataloguing where and how feminist concepts are swallowed and badly digested in sociology. Akin to Skeggs' concern, I am increasingly annoyed and concerned by the amnesia that is spreading over our fields (in my case, gender, media, cultural and queer studies). Sometimes it is because, as Skeggs points out, feminist ideas get incorporated into mainstream disciplines. But I am still astounded that concepts such as the body and embodiment can be routinely rolled out without any mention of the feminist ground of their elaboration. Sometimes it is that university reading lists produce students who have no memory, which is to say that we as lecturers are programming generations to forget. This is not to say that I am advocating a strict canon; quite the opposite. As Gurminda Bhambra pointedly asked at a recent conference on the future of sociology, held in Leeds, 'What's lost when our genealogies become parochial?'5 Following from this, my subtitle directs me to central tenets of Hall's thought that we need to remember and act on within feminist cultural studies now.

And to my title: A feminist love letter to Hall? How presumptuous that sounds, so let me quickly explain. In personal terms, I wouldn't say that I was a friend of 
Hall's. I met him first at the Cultural Studies Now conference in Illinois where, as a shy postgraduate student, I looked on from the edges as the figures who were my theoretical heroes outlined what were to become major tenets of cultural studies when later published in $1992 .{ }^{6}$ They also chatted and ate and acted like normal people. It was in the book that resulted from this conference that Hall wrote about feminism breaking into cultural studies. A bit later I was to ask him for a letter of reference for my application for tenure in sociology at the Université de Montréal. I shook in my boots at the mere thought of asking him but his reply was gracious. His letter was even more so. I got early tenure.

So in one sense, yes, I have much reason to send him a letter if not of love then at least of gratitude. But one of the reasons that I frame this short article as a love letter is that I don't think Hall would mind. This is in stark contrast to another of my intellectual cornerstones, Michel Foucault. As Meaghan Morris has framed it in her inimitable way: 'any feminists drawn in to sending Love Letters to Foucault would be in no danger of reciprocation. Foucault's work is not the work of a ladies' man.'7

Hall's work was and is deeply inspiring for feminism, and gender and queer studies. I have 'taught' Hall to generations of students. While of course this is a problematic phrase when it is only small nuggets of his thought that can be conveyed, I always try to translate something of his persona, of his self, that was so inspiring for my first book, Sexing the Self. ${ }^{8}$ Hall's edited text Representation: Cultural Representations and Signifying Practices is essential for fledgling students of gender and cultural studies. ${ }^{9}$ Alongside this I show my students Sut Jhally and Hall's video Representation \& the Media. ${ }^{10}$ These two texts remain wonderful objects for teaching but it's the audio-visual one that gives a glimpse into the man behind the words. 'Listen', I say to them, 'to his wonderful cadence.' 'Listen to how passion is infused with ideas; ideas with politics.' 'Listen to how he makes ideas matter.'

Writing of Martin Luther King's ability to communicate, James Baldwin states that the:

secret of his greatness does not lie in his voice or his presence or his manner; though it has something to do with all these ... the secret lies, I think, in his intimate knowledge of the people he is addressing, be they black or white, and in the forthrightness with which he speaks of those things which hurt and baffle. 11 
This is what I think Hall gave us. His gift was to address each of us in our individual experiences, our emotional and physical experiences of being hurt and baffledwhen we find ourselves in the strictures of race, class, sexuality and gender not of our own making. The ongoing gift is Hall's complex understanding of what identity means to different people and groups-and how, as scholars, to understand it. He understood that identity was an ongoing journey through the vicissitudes of lived life. He made us realise that 'who speaks, and the subject who is spoken of, are never identical, never exactly in the same place'.12

In his much-cited article influenced by Althusser, Hall gave us a way to understand how we 'live in and within difference'.13 This is an argument that needs repeating when we blunder into conservative ways of thinking about identity. It's an argument that needs flagging when gender studies turns into a machine reproducing stale arguments about 'representation' as sets of media images. This is decidedly not Hall's point when he argued for an understanding of 'the systems of representation in which men and women live ... not blind biological or genetic life, but the life of experiencing, within culture, meaning and representation'.14

Against some of the current ways in which the work of identity as category and as practice has been demeaned as 'identity politics', Hall gave us 'articulation' as the theoretical basis for making sense of how and where we come to identity. Listen once again to the generative way in which Hall uses articulation to open up 'identity' into something so intellectually challenging:

the form of the connection that can make a unity of two different elements, under certain conditions. It is a linkage which is not necessary, determined, absolute and essential for all time. You have to ask, under what circumstances can a connection be forged or made?15

This is the basis from which we can begin to theorise the complex history of any and all formulations of identity.

You can hear this attention to the historical basis of articulation within and across numerous feminist texts. Even as Judith Butler's Gender Trouble is continually misread to frame gender identity as something we can don each morning according to our whim, in her own argument Butler foregrounds how:

the reading of 'performativity' as wilful and arbitrary choice misses the point that the historicity of discourse and, in particular, the historicity of 
norms (the 'chains' of iteration invoked and dissimulated in the imperative utterance) constitute the power of discourse to enact what it names. ${ }^{16}$

As trans* identities become more central in gender studies, along with the challenges they pose to certain feminist tenets, you can still hear the thread of remembrance of the history and temporality of identity. For instance, in Leslie Feinberg's extraordinary 1993 text Stone Butch Blues you can hear the active work of articulation in Feinberg's voice:

It just didn't seem fair. All my life I'd been told everything about me was twisted and sick. But if I was a man, I was 'cute'. Acceptance of me as a he felt like an ongoing indictment of me as a he-she. ${ }^{17}$

Or in the uptake of Deleuze's ideas in feminist examinations, Hall's point echoes: in what circumstances can a connection be forged or made? As Moira Gatens argues, crossing genealogy with the ethology of the sex/gender distinction:

individual human bodies are always considered as parts of larger assemblages, a conceptual frame in which to take account of the variety of ways in which individual bodies and their capacities are affected by their participation in the larger assemblages of families, work and sociopolitical life. 18

Now my point is not that these feminist framings of identity quoted Hall or should have. It is rather that his argument prefigured the bases for analysing identity in ways that remain critical to feminists, to queers, to people of colour, to us all. In the years that followed Hall's grappling with identity, there was an outpouring of such work. While much of it remains important-for instance, Paul Gilroy's 1993 book The Black Atlantic remains fresh and provocative for feminist cultural studies-some, as I suggested with the critiques that misappropriate Butler, are simply dull. Theoretically and politically they do little except offer easy targets for mean-spirited right-wing attacks on our studies. There are too many repetitions of the same that have forgotten why feminism, cultural studies, gender and queer studies are necessary.

I want to conclude my letter to Hall with the words of another feminist. Writing in the collection Without Guarantees: In Honour of Stuart Hall, Michèle Barrett used Hall's work and his passion as a reminder of what she argues sociology had lost: imagination, the physical and the emotional. Her argument is equally a reminder to 
us all, through Hall's example as an academic and an intellectual, that we must seek 'more humanity, more imagination, more perception, more appeal to experience beyond cognition'.19

Elspeth Probyn is Professor of Gender and Cultural Studies, University of Sydney.

\footnotetext{
-NOTES

1 Women's Studies Group, Women Take Issue: Aspects of Women's Subordination, Hutchinson, London, 1978, p. 11.

2 Ibid.

3 Stuart Hall, 'Cultural Studies and its Theoretical Legacies', in Lawrence Grossberg, Cary Nelson and Paula Treichler (eds), Cultural Studies, Routledge, New York, 1992, p. 282.

4 Beverley Skeggs, 'The Dirty History of Feminism and Sociology: Or the War of Conceptual Attrition', The Sociological Review, vol. 56, no. 4, 2008, p. 682.

5 Gurminder Bhambra, 'The Publics of Sociology: Global and Social', paper delivered to the Future Sociologies: Challenges to Practice, Policy and Politics conference, Leeds, 1 July 2015.

${ }^{6}$ Lawrence Grossberg, Cary Nelson and Paula Treichler (eds), Cultural Studies, Routledge, New York, 1992.

7 Meaghan Morris, 'The Pirate's Fiancée', in Meaghan Morris and Paul Patton (eds), Michel Foucault: Power, Truth, Strategy, Feral Publications, Sydney, 1979, p. 152.

8 Elspeth Probyn, Sexing the Self: Gendered Positions in Cultural Studies, Routledge, London, 1993.

${ }_{9}^{9}$ Stuart Hall (ed), Representation: Cultural Representations and Signifying Practices, Sage, London, 1997. 10 Sut Jhally and Stuart Hall, Representation and the Media, Media Education Foundation, New York, 1997.

11 James Baldwin, 'The Dangerous Road before Martin Luther King', Harpers Magazine, February 1961, <http://harpers.org/archive/1961/02/the-dangerous-road-before-martin-luther-king/>.

12 Stuart Hall, 'Cultural Identity and Diaspora', in Jonathan Rutherford (ed.), Identity: Community, Culture, Difference, Lawrence \& Wishart, London, 1990, p. 222.

13 Stuart Hall, 'Signification, Representation, Ideology: Althusser and the Post-Structuralist Debates', Critical Studies in Mass Communication, vol. 2, no. 2, 1985, p. 92.

14 Ibid., p. 104.

15 Stuart Hall, 'On Postmodernism and Articulation: An Interview with Stuart Hall', Lawrence Grossberg (ed.), Journal of Communication Inquiry, vol. 10, no. 2, 1986, p. 53.

16 Judith Butler, Gender Trouble, Routledge, New York, 1990, p. 187.
} 
17 Feinberg cited in Anika Stafford, 'Departing Shame: Feinberg and Queer/Transgender CounterCultural Remembering', Journal of Gender Studies, vol. 21, no. 3, 2012, p. 308.

18 Moira Gatens, 'Sex, Gender, Sexuality: Can Ethologists Practice Geneaology?', The Southern Journal of Philosophy, vol. 35, Supplement, 1996, p. 11.

${ }^{19}$ Michèle Barrett, 'Sociology and The Metaphorical Tiger', in Paul Gilroy, Lawrence Grossberg and Angela McRobbie (eds), Without Guarantees: In Honour of Stuart Hall, Verso, London, 2000, p. 20.

\section{-BiBLIOGRAPHY}

Baldwin, J., 'The Dangerous Road before Martin Luther King', Harpers Magazine, February 1961, <http://harpers.org/archive/1961/02/the-dangerous-road-before-martin-luther-king/>.

Barrett, M., 'Sociology and The Metaphorical Tiger', in P. Gilroy, L. Grossberg and A. McRobbie (eds), Without Guarantees: In Honour of Stuart Hall, Verso, London, 2000.

Bhambra, G., 'The Publics of Sociology: Global and Social', paper delivered to the Future Sociologies: Challenges to Practice, Policy and Politics conference, Leeds, 1 July 2015.

Butler, J., Gender Trouble, Routledge, New York, 1990.

Gatens, M., 'Sex, Gender, Sexuality: Can Ethologists Practice Geneaology?', The Southern Journal of Philosophy, vol. 35, Supplement, 1996.

Gilroy, P., The Black Atlantic: Modernity and Double Consciousness, Harvard University Press, Cambridge, 1993.

Grossberg, L., C. Nelson, and P. Treichler (eds), Cultural Studies, Routledge, New York, 1992.

Hall, S. (ed.), Representation. Cultural Representations and Signifying Practices, Sage, London, 1997.

Hall, S., 'Cultural Studies and its Theoretical Legacies', in L. Grossberg, C. Nelson and P. Treichler (eds), Cultural Studies, Routledge, New York, 1992.

Hall, S., 'Cultural Identity and Diaspora', in J. Rutherford (ed.), Identity: Community, Culture, Difference, Lawrence \& Wishart, London, 1990.

Hall, S., 'On Postmodernism and Articulation: An Interview with Stuart Hall', L. Grossberg (ed.), Journal of Communication Inquiry, vol. 10, no. 2, 1986.

Hall, S., 'Signification, Representation, Ideology: Althusser and the Post-Structuralist Debates', Critical Studies in Mass Communication, vol. 2, no. 2, 1985. doi: http://dx.doi.org/10.1080/15295038509360070

Jhally, S. and S. Hall, Representation \& the Media, Media Education Foundation, New York, 1997.

Morris, M. 'The Pirate's Fiancée', in M. Morris and P. Patton (eds), Michel Foucault: Power, Truth, Strategy, Feral Publications, Sydney, 1979.

Probyn, E. Sexing the Self: Gendered Positions in Cultural Studies, Routledge, London, 1993. doi: http://dx.doi.org/10.4324/9780203167854 
Skeggs, B., 'The Dirty History of Feminism and Sociology: Or the War of Conceptual Attrition', The Sociological Review, vol. 56, no. 4, 2008. doi: http://dx.doi.org/10.1111/j.1467954X.2008.00810.X

Stafford, A., 'Departing Shame: Feinberg and Queer/Transgender Counter-Cultural Remembering', Journal of Gender Studies, vol. 21, no. 3, 2012. doi: http://dx.doi.org/10.1080/09589236.2012.691645

Women's Studies Group, Women Take Issue: Aspects of Women's Subordination, Hutchinson, London, 1978. 